\title{
KAJIAN YURIDIS KEDUDUKAN HUKUM TANAH PECATU DESA LENEK KABUPATEN LOMBOK TIMUR
}

\author{
Firzhal Arzhi Jiwantara, Fakultas Hukum, Universitas Muhammadiyah \\ Mataram Lombok, NTB, Indonesia, E-mail : Firzhal@yahoo.com
}

Erwin Indomora, Program Studi Doktor Ilmu Hukum Universitas 17 Agustus

1945 Surabaya, E-mail: erwinindomora1618@yahoo.com

doi: https://doi.org/10.24843/KS.2020.v09.i01.p07

\begin{abstract}
ABSTRAK
Tujuan penelitian dalam studi ini menemukan pemahaman yang konstruktif normatif atas permasalahan atau isu hukum hak atas tanah pecatu. Penelaahan pemahaman berorientasi pada konstruksi dialektik idealisme positifisme dalam pendekatan fungsional imperatif, yang menyoroti perihal struktur dan aksi berkenaan dengan hak atas tanah pecatu. Diharapkan melalui penelitian ini dapat ditemukan pemahaman yang berguna bagi upaya perwujudan harmonisasi hukum pada masyarakat. Jenis penelitian ini adalah penelitian hukum normatif, bahwa Penelitian hukum normatif adalah penelitian yang mencakup penelitian terhadap asasasas hukum, penelitian terhadap sistematika hukum, penelitian terhadap sinkronisasi hukum, penelitian sejarah hukum, dan penelitian perbandingan hukum. Berdasarkan kebutuhan dalam penelitian ini, maka penelitian ini menggunakan beberapa pendekatan, yaitu Perundangundangan (statute approach) sebagai dasar dalam penelitian dalam mengacu dasar-dasar hukum pertimbangan hakim berdasarkan peraturan-perundang-undangan, Pendekatan Konsep (conceptual approach) sebagai acuan dalam menganilis status tanah pecatu berdasarkan kepustakaan, serta Pendekatan Kasus (case approach) dalam hal ini kasus tanah pecatu desa lenek Pecatu Desa Desa Lenek Kecamatan Aikmel, (sekarang Kecamatan Lenek), Kabupaten Lombok Timur.
\end{abstract}

Kata Kunci: Kajian Yuridis, Kedudukan Hukum, Tanah Pecatu, Desa Lenek.

\section{ABSTRACT}

The research objective in this study is to find a constructive, normative understanding of the problem or legal issue of land rights in Pecatu. The study of understanding is oriented to the dialectical construction of positivist idealism in the imperative functional approach, which focuses on the structure and actions regarding the land rights in Pecatu. It is hoped that through this research, we can find an understanding that is useful for the realization of legal harmonization in society. This type of research is normative legal research, that normative legal research is research that includes research on legal principles, research on legal systematics, research on legal synchronization, legal history research, and comparative legal research. Based on the needs of this research, this study uses several approaches, namely statute approach as the basis for research in referring to the legal basics of judges' considerations based on statutory regulations, conceptual approach as a reference in analyzing Pecatu land status is based on literature, as well as the Case Approach, in this case the land of Pecatu, Lenek Pecatu Village, Lenek Village, Aikmel District, (now Lenek District), East Lombok Regency.

Keywords: Juridical Study, Legal Position, Pecatu Land, Lenek Village. 


\section{Pendahuluan}

\subsection{Latar Belakang Masalah}

Tanah merupakan salah satu sumber daya alam yang sangat penting bagi kehidupan manusia, oleh karena itu negara telah memberikan landasan yang kokoh dalam hal pemanfaatan tanah sebagai sumber daya alam tersebut, sebagaimana diatur dalam Pasal 33 ayat (3) Undang-Undang Dasar 1945, bahwa: "Bumi, air dan kekayaan alam yang terkandung di dalamnya dikuasai oleh negara dan digunakan sebesarbesarnya bagi kemakmuran rakyat."

Atas dasar ketentuan Pasal 33 ayat (3) Undang-Undang Dasar Negara Republik Indonesia 1945 maka lahirlah Undang-Undang Nomor 5 Tahun 1960 tentang Peraturan Dasar Pokok-Pokok Agraria, dan negara sebagai organisasi kekuasaan seluruh rakyat. Namun dalam Undang-Undang Pokok Agraria tidak secara lengkap menyebut tentang tanah pecatu, tetapi tanah pecatu dikategorikan sebagai hak ulayat dengan alasan tanah pecatu masih diatur dengan ketentuan hukum adat setempat dan melekat hak komunal yang secara umum terdapat dalam Pasal 3 Undang-Undang Pokok Agraria yang menyebutkan:

"Pelaksanaan hak ulayat dan hak-hak serupa itu dari masyarakat hukum adat, sepanjang menurut kenyataannya masih ada, harus sedemikian rupa sehingga sesuai dengan kepentingan nasional dan negara, yang berdasarkan atas persatuan bangsa dan tidak boleh bertentangan dengan undang-undang dan peraturan-peraturan yang lebih tinggi".

Pengakuan tanah pecatu dalam UUPA harus memenuhi dua syarat yaitu eksistensi dan pelaksanaannya. Pengakuan tanah pecatu juga diakui sepanjang menurut keadaan dan kenyataannya masih ada dalam suatu daerah. Jika di daerahdaerah tertentu tidak pernah ada, maka daerah tersebut harus menyediakan tanah pecatu, karena syarat pembentukan desa harus tersedianya wilayah, masyarakat dan memiliki tanah pecatu.

Menurut pandangan Anang Husni ${ }^{1}$, bahwa tanah pecatu sebagai milik negara/ pemerintah daerah tidak dibenarkan, karena hukum menguasai negara merupakan domain public, sedangkan hak ulayat adalah domain kolektif yang tetap berada pada domain privat. Karena pemerintahan ini bukanlah salah satu bentuk masyarakat hukum adat. Hal ini sesuai dengan norma yang terkandung dalam prinsip konstitusi, khususnya dalam pasal 33 ayat 3 dan pasal 18B ayat 2 UUD 1945.

Tanah Pecatu Desa Lenek merupakan salah satu contoh domain public yang dikembalikan kepada domain privat, yaitu setelah berlaku Undang-Undang Nomor 6 Tahun 2014 tentang Pemerintahan Desa, yang mengatur aset desa harus dipisahkan dengan aset daerah, selanjutnya atas persetujuan DPRD Kabupaten Lombok Timur disusul Surat Keputusan Bupati tanggal 1 Juli 2014 Nomor 188.45/319/PPKA/2014, tanah objek sengketa sebagai aset negara di Kabupaten Lombok Timur (Menteri Keuangan RI) diserahkan kepada Desa sebagai Tanah Pecatu. Namun disi lain Tanah pecatu Desa Lenek Kecamatan Aikmel, (sekarang Kecamatan Lenek), Kabupaten Lombok Timur tersebut diklaim oleh ahli waris Papuq Djamilah bahwa tanah tersebut merupakan tanah sengketa yang merupakan peninggalan almarhum Papuq Djamilah dengan berdasarkan bukti surat girik yang diterbitkan sebelum Indonesia merdeka yaitu sebelum tahun 1940.

${ }^{1}$ Anang Husni, Hak Atas Tanah Pecatu Desa Berdasarkan Prinsip Mengusai Oleh Negara. Jurnal IUS Vol III Nomor 8 Agustus 2015, Kajian Hukum dan Keadilan 311 339, (2013). 
Ahli waris Papuq menyatakan bahwa tanah sengketa nomor pipil 180, nomor persil 87 kelas II dengan luas $\pm 2.480 \mathrm{Ha}$ atau \pm 2 Hektar 48 are, dengan batas-batas sebagai berikut: - Sebelah Utara tanah H. Jamil, tanah Papuq Temah dan Inaq Kesim; Sebelah Selatan perkampungan dan tanah Papuq Ugik; - Sebelah Timur parit dan Jalan; - Sebelah Barat parit dan Tanah Papuq Jamilah pipil Nomor 139; Dan tanah sengketa dengan nomor pipil 139, nomor persil 87 kelas II dengan luas $\pm 2.300 \mathrm{Ha}$ atau \pm 2 Hektar 30 are dengan batas-batas sebagai berikut: - Sebelah Utara tanah Papuq Temah dan Tanah Inaq Kesim; - Sebelah Selatan tanah Amaq Kaliah, Papuq Kiam dan Papuq Ugik; - Sebelah Timur parit dan Tanah Papuq DJamilah pipil Nomor 180; Sebelah Barat pecahan Tanah Papuq DJamilah pipil Nomor 139 Adalah peninggalan almarhum Papuq Djamilah;

Kakek moyang Penggugat yaitu almarhum Papuq Djamilah sebelum tahun 1940 tidak pernah menguasai dan sepanjang hidupnya tidak pernah keberatan atas penguasaan tanah oleh pemerintah desa pada saat itu, juga almarhum Among Rawan yang merupakan kakek Penggugat sepanjang hidupnya tidak menguasai tanah objek sengketa dan tidak pernah menyatakan keberatan, demikian juga almarhum Awang yang merupakan orang tua dari Penggugat, sepanjang hidupnya tidak menguasai dan tidak pernah keberatan atas tanah objek sengketa sebagai tanah pecatu, selain itu tiga generasi tersebut tidak pernah mengkonversi surat girik tersebut sebagaimana diharuskan oleh peraturan hukum pertanahan, maka Penggugat tidak dapat dinyatakan sebagai pemilik tanah objek sengketa.

Perkara tersebut telah berkekuatan hukum tetap dan telah diputuskan oleh mahkamah Agung RI sebagai tanah pecatu dalam Peninjauan Kembali berdasarkan putusan Mahkamah Agung RI Nomor 287 PK/Pdt / 2019.

Putusan tersebut merupakan hal yang menarik untuk dikaji, dimana terdapat perbedaan pandangan antara penggugat dengan tergugat, serta pertimbangan hakim dalam memberikan amar putusan berdasarkan peraturan dan perundang-undangan terkait status tanah Pecatu Desa Lenek Kecamatan Aikmel, (sekarang Kecamatan Lenek), Kabupaten Lombok Timur. Salah satu diantaranya dasar pertimbangan bukti girik fisik tanah tidak pernah dikuasai dalam kurun waktu kurang lebih 70 tahun, tidak dapat dijadikan dasar kepemilikan (yurisprudensi tetap Mahkamah Agung), sebaliknya pihak yang menguasai yaitu Pemerintahan Kabupaten Lombok Timur sekarang Desa sebagai pemilik pecatu yang menguasai kurang lebih selama 70 tahun dan sudah didaftar sebagai aset negara (tanah pecatu) tanggal 10 Januari 1950, berdasarkan hukum pertanahan nasional dinyatakan sebagai pemilik (yurisprudensi tetap Mahkamah Agung).

\subsection{Rumusan Masalah}

Berdasarkan uraian diatas, maka dapat diajukan rumusan dalam penelitian ini yaitu; bagaimana status atau kedudukan hukum tanah Pecatu Desa Desa Lenek Kecamatan Aikmel, (sekarang Kecamatan Lenek), Kabupaten Lombok Timur berdasarkan Putusan Mahkamah Agung RI Nomor 287 PK/Pdt / 2019.

\subsection{Tujuan Penelitian}

Penelitian ini lebih memfokuskan pada kajian mendalam kaitannya dengan status hukum keberadaan tanah pecatu dari hukum adat yang notabene dijadikan landasan hukum pertanahan di Indonesia. Tujuan penelitian dalam studi ini menemukan pemahaman yang konstruktif normatif atas permasalahan atau isu hukum hak atas tanah pecatu. Penelaahan pemahaman berorientasi pada konstruksi 
dialektik idealisme positifisme dalam pendekatan fungsional imperatif, yang menyoroti perihal struktur dan aksi berkenaan dengan hak atas tanah pecatu. Diharapkan melalui penelitian ini dapat ditemukan pemahaman yang berguna bagi upaya perwujudan harmonisasi hukum pada masyarakat.

\section{Metode Penelitian}

Jenis penelitian ini adalah penelitian hukum normatif, sesuai dengan pendapat yang diungkapkan oleh Soerjono Soekanto, ${ }^{2}$ sebagaimana yang dikutip oleh Mukti Fajar $\mathrm{ND}^{3}$ bahwa Penelitian hukum normatif adalah penelitian yang mencakup penelitian terhadap asas-asas hukum, penelitian terhadap sistematika hukum, penelitian terhadap sinkronisasi hukum, penelitian sejarah hukum, dan penelitian perbandingan hukum.

Penelitian hukum (legal research) ${ }^{4}$ merupakan karakter khas dari ilmu hukum (jurisprudence), ${ }^{5}$ guna menjawab permasalahan atau isu hukum yang hendak dikaji dalam penelitian. Dalam penelitian hukum tersebut, diperlukan suatu metode pendekatan yang disesuaikan dengan persoalan yang akan diteliti.

Jhonny Ibrahim mengemukakan bahwa terdapat beberapa pendekatan dalam penelitian hukum normatif, yaitu: ${ }^{6}$
a. Pendekatan Perundang-undangan (statute approach);
b. Pendekatan Konsep (conceptual approach);
c. Pendekatan Analitis (analytical approach);
d. Pendekatan Perbandingan (comparative approach);
e. Pendekatan Historis (historical approach);
f. Pendekatan Filsafat (philosofical approach);
g. Pendekatan Kasus (case approach).

Berdasarkan kebutuhan dalam penelitian ini, maka penelitian ini menggunakan beberapa pendekatan, yaitu Perundang-undangan (statute approach) sebagai dasar dalam penelitian dalam mengacu dasar-dasar hukum pertimbangan hakim berdasarkan peraturan-perundang-undangan, Pendekatan Konsep (conceptual approach) sebagai acuan dalam menganilis status tanah pecatu berdasarkan kepustakaan, serta Pendekatan Kasus (case approach) dalam hal ini kasus tanah pecatu desa lenek Pecatu Desa Desa Lenek Kecamatan Aikmel, (sekarang Kecamatan Lenek), Kabupaten Lombok Timur.

Sumber Dan Jenis Bahan Data: Data Primer, yaitu bahan hukum yang terdiri dari peraturan Perundang-undangan yang terkait dengan permasalahan yang diangkat tentang status tanah pecatu. Data Sekunder, yaitu bahan hukum yang diperoleh dari buku, jurnaljurnal buku, pendapat para sarjana, serta symposium yang dilakukan oleh pakar terkait dengan permasalahan yang diangkat dalam penelitian mengenai Status

2Soerjono Soekanto, Pengantar Penelitian Hukum, Jakarta: Universitas Indonesia Press, (1983), hlm.51.

${ }^{3}$ Mukti Fajar ND, Dualisme Penelitian Hukum Normatif dan Empiris, Yogyakarta: Pustaka Pelajar, (2010), hlm.153.

${ }^{4}$ Peter Mahmud Marzuki, Penelitian Hukum, Jakarta: Prenada Media, (2008), hlm. 29-33

5J.J. Brugink, Rechtsreflecties, Alih bahasa Arif Sidartha, Bandung: Citra Aditya Bakti, (1995), hlm. 213-218

${ }^{6}$ Jhonny Ibrahim, ,Teori dan Metode Penemuan Hukum Normatif, Malang: Banyumedia, (2005), hlm. 300 
Tanah Pecatu dalam kaitannya dengan tanah pecatu desa lenek Pecatu Desa Desa Lenek Kecamatan Aikmel, (sekarang Kecamatan Lenek), Kabupaten Lombok Timur. Data Tersier, yaitu bahan hukum yang memberikan petunjuk atau penjelasan bermakna terhadap bahan hukum primer dan skunder, seperti kamus hukum di bidang Pengaturan tanah.

\section{Hasil dan Pembahasan}

Mahkamah Agung mengabulkan permohonan Peninjauan Kembali dari ParaPemohon melalui Putusan Mahkamah Agung Nomor 287PK/Pdt/2019perihalpermohonan Peninjauan Kembali atas Putusan Mahkamah Agung Nomor 1370K/Pdt/2016 tanggal 8 November 2016 tentang pengelolaan tanah sengketa oleh Pemerintah Desa Lenek, Kecamatan Aikmel, Kabupaten Lombok Timur.

Perkara tersebut berawal dari Para Penggugat yaitu Gunawan alias Amaq Jun beserta keluarganya ahli waris Papuq Djamilah dan Pemda Tk II Kab. Lombok Timur Cq, Bupati Lombok Timur yang merasa keberatan atas pengelolaan Tanah Pecatu Desa Lenek Kecamatan Aikmel, Kabupaten Lombok Timur, serta mengklaim bahwa Tanah Pecatu Desa Lenek tersebut merupakan Tanah Warisan Papuq Djamilah dengan mengajukan gugatan tersebut kepada Pengadilan Negeri Selong.

Gugatan tersebut oleh Pengadilan Negeri Selong telah diberikan Putusan Nomor 72/Pdt.G/2014/PN.Sel tanggal 30 April 2015 dengan amar sebagai berikut:

Dalam Eksepsi: - Menolak eksepsi Para Tergugat seluruhnya;

Dalam Pokok Perkara:

- Menolak gugatan Penggugat untuk seluruhnya;

- Menghukum Para Turut Tergugat untuk tunduk dan patuh terhadap Putusan ini;

- Menghukum Penggugat untuk membayar biaya perkara yang ditetapkan sejumlah Rp7.126.000,00,- (Tujuh juta seratus dua puluh enam ribu rupiah);

Perkembangannya dalamamar Putusan Pengadilan Tinggi Mataram Nomor 127/PDT/2015/PT.MTR tanggal 30 November 2015 adalah sebagai berikut:

1. Menerima permohonan banding dari Penggugat/Pembanding;

2. Membatalkan putusan Pengadilan Negeri Selong Nomor 72/Pdt.G/2014/ PN.Sel, tanggal 30 April 2015, yang dimohonkan banding tersebut;

Perkara tersebut selanjutnya dalam kasasi berdasarkan amar Putusan Mahkamah Agung RI Nomor 1370 K/Pdt/2016 tanggal 8 Nopember 2016 yang telah berkekuatan hukum tetap tersebut adalah sebagai berikut:

1. Menolak permohonan kasasi dari Para Pemohon Kasasi I: 1. KEPALA DESA LENEK, 2. KAUR KESRA DESA LENEK, 3. KAUR PEMERINTAHAN DESA LENEK, 4. KADUS DASAN MONTONG DESA LENEK, 5. KADUS PAOK PONDONG DESA LENEK, 6. KADUS KARANG TEMBAR DESA LENEK, 7. KADUS KOLOH MOTONG DESA LENEK, 8. KADUS GUBUK JERO DESA LENEK, 9. KADUS KEROAK DESA LENEK DAYA, 10. KADUS RAMBAN BIAK DESA LENEK RAMBAN BIAK, 11. KADUS KOLOH PETUNG BARAT DESA LENEK PESIRAMAN, 12. KADUS KOLOH PETUNG TIMUR DESA LENEK PESIRAMAN, 13. KADUS KALIBAMBANG, DESA LENEK KALIBAMBANG, 14. AMAQ NUKMAN KADUS DASAN MONTONG, 15. AMAQ TONI, 16. HAJI OPIK, 17. HAJI NOAR, 18. AMAQ WIN, Pemohon Kasasi II: PEMERINTAH DAERAH TINGKAT II KABUPATEN LOMBOK TIMUR cq BUPATI LOMBOK TIMUR tersebut; 
2. Menghukum Pemohon Kasasi I, Pemohon Kasasi II/Para Tergugat $2 \mathrm{~s} / \mathrm{d}$ 19, Tergugat $1 /$ Terbanding $1 \mathrm{~s} / \mathrm{d} 19$ untuk membayar biaya perkara dalam tingkat kasasi ini sejumlah Rp500.000,00 (lima ratus ribu rupiah);

Mahkamah Agung dalam putusannya Nomor 287PK/Pdt/2019 memberikan amar putusan sebagai berikut:

- Mengabulkan permohonan Peninjauan Kembali dari Para Pemohon Peninjauan Kembali: 1. KEPALA DESA LENEK, 2. KAUR KESRA DESA LENEK, 3. KAUR PEMERINTAHAN DESA LENEK, 4. KADUS DASAN MONTONG DESA LENEK, 5. KADUS PAOK PONDONG DESA LENEK, 6. KADUS KARANG TEMBAR DESA LENEK, 7. KADUS KOLOH MOTONG DESA LENEK, 8. KADUS GUBUK JERO DESA LENEK, 9. KADUS KEROAK DESA LENEK DAYA, 10. KADUS RAMBAN BIAK DESA LENEK RAMBAN BIAK, 11. KADUS KOLOH PETUNG BARATDESA LENEK PESIRAMAN, 12. KADUS KOLOH PETUNG TIMUR DESA LENEK PESIRAMAN, 13.KADUS KALIBAMBANG DESA LENEKKALIBAMBANG, 14 . AMAQ NUKMAN KADUS DASAN MONTONG, 15. AMAQ TONI, 16. HAJI OPIK, 17. HAJI NOAR, 18. AMAQ WIN, tersebut;

- Membatalkan Putusan Mahkamah Agung Nomor 1370 K/Pdt/2016 tanggal 8 November 2016;

\section{MENGADILI KEMBALI:}

Dalam Eksepsi: - Menolak eksepsi Para Tergugat seluruhnya;

Dalam Pokok Perkara:

1. Menolak gugatan Penggugat untuk seluruhnya;

2. Menghukum Termohon Peninjauan Kembali untuk membayar biaya perkara pada semua tingkat peradilan, yang dalam peninjauan kembali ini sebesar Rp2.500.000,00 (dua juta lima ratus ribu rupiah);

\section{Domain Privat Tanah Pecatu}

Tanah Pecatu Desa Lenek merupakan salah satu contoh domain public yang dikembalikan kepada domain privat, yaitu setelah berlaku Undang-Undang Nomor 6 Tahun 2014 tentang Pemerintahan Desa, yang mengatur aset desa harus dipisahkan dengan aset daerah, selanjutnya atas persetujuan DPRD Kabupaten Lombok Timur disusul Surat Keputusan Bupati tanggal 1 Juli 2014 Nomor 188.45/319/PPKA/2014, tanah objek sengketa sebagai aset negara di Kabupaten Lombok Timur (Menteri Keuangan RI) diserahkan kepada Desa sebagai Tanah Pecatu.

Menurut pandangan Anang Husni ${ }^{7}$, bahwa tanah pecatu sebagai milik negara/ pemerintah daerah tidak dibenarkan, karena hukum menguasai negara merupakan domain public, sedangkan hak ulayat adalah domain kolektif yang tetap berada pada domain privat. Karena pemerintahan ini bukanlah salah satu bentuk masyarakat hukum adat. Hal ini sesuai dengan norma yang terkandung dalam prinsip konstitusi, khususnya dalam pasal 33 ayat 3 dan pasal 18B ayat 2 UUD 1945.

Kedua landasan konstitusional tersebut, yakni Pasal 33 dan Pasal 18B ayat (2) UUD 1945 dipertemukan dalam Ketetapan MPR No. IX/2001/MPR tentang Pembaruan Agraria dan Pengelolaan Sumber Daya Alam. Ketetapan MPR ini memiliki kedudukan penting selain sebagai bentuk koreksi terhadap kebijakan dan peraturan

${ }^{7}$ Anang Husni,. Hak Atas Tanah Pecatu Desa Berdasarkan Prinsip Mengusai Oleh Negara. Jurnal IUS Vol III Nomor 8 Agustus 2015, Kajian Hukum dan Keadilan 311 339, (2013) 
perundang-undangan yang berkaitan dengan agraria dan pengelolaan sumber daya alam pada masa lalu, Ketetapan MPR ini juga merupakan prinsip-prinsip pemandu kebijakan negara (directive principles of state policy) yang dibuat pada masa reformasi. Dengan demikian, Ketetapan MPR ini merupakan pemandu bagi pemerintah dan DPR dalam melakukan perubahan hukum berkaitan dengan agraria dan pengelolaan sumber daya alam termasuk dalam kaitannya untuk mengakui keberadaan dan hak tradisional masyarakat hukum adat atas tanah dan sumber daya alam.

Pengakuan dan penghormatan Pasal 18B ayat (2) UUD 1945 tentang kesatuankesatuan masyarakat hukum adat serta hak-hak tradisonalnya sepanjang masih hidup dan sesuai dengan perkembangan masyarakat dan prinsip Negara Kesatuan Republik Indonesia, yang diatur dengan Undang-Undang. Landasan ini memisahkan antara satuan pemerintahan daerah yang diberi otonomi dengan kesatuan masyarakat hukum. Urusan yang dikelola oleh satuan pemerintahan daerah menunjukkan pemencaran kekuasaan, sementara, sepanjang masih ada, urusan yang dikelola oleh Desa merupakan pengakuan. Tentunya tetap dimungkinkan terdapat tugas pembantuan yang diberikan oleh Kabupaten, Provinsi, maupun Pemerintah Pusat. ${ }^{8}$

Dasar konstitusional mengenai keberadaan dan hak tradisional masyarakat hukum adat terdapat pada Pasal 18B ayat (2) UUD 1945 yang menyatakan bahwa: Negara mengakui dan menghormati kesatuan masyarakat hukum adat beserta hak tradisionalnya sepanjang masih ada dan sesuai dengan perkembangan zaman, tidak bertentangan dengan prinsip Negara Kesatuan Republik Indonesia, dan diatur dalam undang-undang. Ketentuan ini membatasi keberadaan dan hak tradisional masyarakat hukum adat, termasuk haknya atas tanah dan sumber daya alam.

Meski sudah mengakui dan menghormati keberadaan masyarakat adat beserta hak ulayatnya secara deklaratif, Pasal 18B ayat (2) mencantumkan beberapa persyaratan yang harus dipenuhi suatu masyarakat untuk dapat dikategorikan sebagai masyarakat (hukum) adat beserta hak ulayat yang dapat dimanfaatkannya.

Persyaratan-persyaratan tersebut secara kumulatif adalah: ${ }^{9}$

a. Sepanjang masih hidup

b. Sesuai dengan perkembangan masyarakat

c. Sesuai dengan prinsip NKRI

d. Diatur dalam Undang-undang

Rikardo Simarmata ${ }^{10}$ menyebutkan bahwa persyaratan terhadap masyarakat adat dan hak ulayatnya yang dilakukan oleh UUD 1945 setelah amandemen memiliki sejarah yang dapat dirunut dari masa kolonial. Persyaratan terhadap masyarakat adat sudah ada di dalam Aglemene Bepalingen (1848), Reglemen Regering (1854) dan Indische Staatregeling (1920 dan 1929) yang mengatakan bahwa orang pribumi dan timur asing

${ }^{8}$ R. Yando Zakaria, Makna Amandemen Pasal 18 UUD 1945 bagi Pengakuan dan Perlindungan Masyarakat Adat di Indonesia, Makalah yang disampaikan pada Konferensi dan Dialog Nasional dalam rangka Satu Dasawarsa Amandemen UUD 1945 dengan tema “NEGARA HUKUM INDONESIA KE MANA AKAN MELANGKAH?” (2012), Diselenggarakan di Jakarta, tanggal 9-10 Oktober 2012

${ }^{9}$ Herlambang P Wiratraman, , Laporan Akhir Tim Pengkajian Konstitusi Tentang Perlindungan Hukum Terhadap Masyarakat Hukum Adat, Jakarta: BPHN kemenkumham RI, (2014), hlm. 25

${ }^{10}$ Rikardo Simarmata, Pengakuan Hukum terhadap Masyarakat Adat Indonesia, Jakarta: UNDP, (2006), hlm. 309 
yang tidak mau tunduk kepada hukum Perdata Eropa, diberlakukan undang-undang agama, lembaga dan adat kebiasaan masyarakat, "sepanjang tidak bertentangan dengan asasasas yang diakui umum tentang keadilan.

Status Tanah pecatu Di Desa Lenek merupakan tanah yang secara turun temurun telah dikelola oleh masyarakat adat Desa Lenek dalam hal ini oleh Pejabat desa dari Kepala Desa, Kepala Urusan Kesra, Kepala Urusan desa, Kepala Dusun. Hal tersebut berarti bahwa penguasaan tanah tersebut yang kemudian menjadi tanah pecatu sudah berlangsung lama dan telah diakui oleh negara, sebagaimana tertuang dalam amar pertimbangan majelis hakim berikut:

Bahwa Almarhum Pauq Djamilah sebagai kakek moyang Penggugat atau ayah dari Kakek Penggugat meninggal dunia tahun 1940, tanah objek sengketa telah dikuasai dan telah dijadikan tanah pecatu, yang setelah Indonesia merdeka tepatnya tanggal 10 Januari 1950 dicatatkan secara resmi sebagai tanah pecatu kemudian menjadi aset di Kabupaten Mataram, tanah itu dikuasai secara terus menerus dan setelah berlaku Undang-Undang Nomor 6 Tahun 2014 tentang Pemerintahan Desa, yang mengatur aset desa harus dipisahkan dengan aset daerah, selanjutnya atas persetujuan DPRD Kabupaten Lombok Timur disusul Surat Keputusan Bupati tanggal 1 Juli 2014 Nomor 188.45/319/PPKA/2014, tanah objek sengketa sebagai aset negara di Kabupaten Lombok Timur (Menteri Keuangan RI) diserahkan kepada Desa sebagai Tanah Pecatu Desa Lenek.

Hal tersebut menunjukkan fakta yang memperkuat posisi Tergugat (Kepala Desa Lenek beserta jajarannya yang mengelola Tanah Pecatu Desa Lenek) sebagai Tergugat/Pemohon Peninjauan Kembali telah menguasai tanah sengketa sejak tahun 1950 atas dasar tanah pecatu atau tanah desa.

Surat Keputusan Bupati tanggal 1 Juli 2014 Nomor 188.45/319/PPKA/2014, tanah objek sengketa sebagai aset negara di Kabupaten Lombok Timur (Menteri Keuangan RI) diserahkan kepada Desa sebagai Tanah Pecatu Desa Lenek merupakan hal yang sudah sesuai dengan Undang-Undang Nomor 6 tahun 2014 tentang Desa, diantaranya dalam pasal 76 yang menyebutkan;

Ayat (1) Aset Desa dapat berupa tanah kas Desa, tanah ulayat, pasar Desa, pasar hewan, tambatan perahu, bangunan Desa, pelelangan ikan, pelelangan hasil pertanian, hutan milik Desa, mata air milik Desa, pemandian umum, dan aset lainnya milik Desa."

Ayat (3) Kekayaan milik Pemerintah dan Pemerintah Daerah berskala lokal Desa yang ada di Desa dapat dihibahkan kepemilikannya kepada Desa."

Ayat (5) Kekayaan milik Desa yang telah diambil alih oleh Pemerintah Daerah Kabupaten/Kota dikembalikan kepada Desa, kecuali yang sudah digunakan untuk fasilitas umum.

Tanah pecatu merupakan Domain Privat, sehingga hak penguasaan Negara atas tanah pecatu dalam hal ini Pemerintah Kota/Kabupaten dikembalikan kepada Desa. Hak Menguasai oleh Negara (HMN) adalah domain public sebutan yang diberikan oleh UUPA kepada lembaga hukum dan hubungan hukum konkret antara Negara, warga masyarakat dan tanah Indonesia. HMN pada dasarnya merupakan kewenangan Negara yang bersumber pada Konstitusi Negara, Pasal 33 Undang-Undang Dasar Negara Republik Indonesia 1945 (UUDNRI 1945), yang dalam Ayat 3, menyatakan:

"Bumi, air, dan kekayaan alam yang terkandung di dalamnya dikuasai oleh Negara dan dipergunakan untuk sebesar-besarnya kemakmuran rakyat." 
Pengelolaan Kekayaan Negara yang bersumber pada Pasal 33 ayat 3 UUDNRI 1945, Negara adalah badan penguasa atas sumber daya alam dengan Hak Menguasai dikelola dengan tujuan untuk sebesar-besarnya kemakmuran rakyat. Lembaga pemerintahan atau instansi pengelolanya adalah instansi pemerintah departemen yang diberikan wewenang untuk itu. Bukan dalam makna negara memiliki, tetapi dalam pengertian bahwa negara hanya merumuskan kebijakan (beleid), melakukan pengaturan (regelendaad), melakukan pengurusan (bestuursdaad), melakukan pengelolaan (beheersdaad), dan melakukan pengawasan (toezichthoundendaad).

Kewenangan ini lebih luas dan menjelaskan isi Pasal 2 Ayat 2 UUPA: Hak menguasai dari negara memberi wewenang:

a. Mengatur dan menyelenggarakan peruntukan, penggunaan, persediaan, dan pemeliharaan bumi, air, dan ruang angkasa tersebut:

b. Menentukan dan mengatur hubungan hukum antara orang dengan bumi, air, dan ruang angkasa:

c. Menentukan dan mengatur hubungan-hubungan hukum antara orangorang dan perbuatan-perbuatan hukum yang mengenai bumi, air, dan ruang angkasa.

Kemudian dalam Pasal 2 Ayat 3 UUPA, menyebutkan: Wewenang yang bersumber pada hak menguasai dari negara tersebut pada ayat 2 Pasal ini digunakan untuk mencapai sebesar besarnya kemakmuran rakyat dalam arti kebangsaan, kerakyatan dan kemerdekaan dalam masyarakat dan negara hukum yang merdeka, berdaulat, adil dan makmur.

Dari uraian singkat tersebut, dapat diketahui bahwa semua hak atas tanah bertujuan untuk membina kemakmuran rakyat, dan secara juridik tidak menghilangkan keharusan mendaftarkan hak atas tanah untuk mewujudkan jaminan kepastian hukum. Hal itu berlaku bagi semua instansi dan departemen dalam menguasai tanah. Ironisnya, dewasa ini pendaftaran hak atas tanah belum seluruhnya dilaksanakan, demikian pula Tanah Pecatu sebagai domain privat masyarakat desa, bukan sebagai domain public Pemerintahan

\section{Status Bukti Girik Tanah}

Putusan Mahkamah Agung RI Putusan Mahkamah Agung Nomor 287PK/Pdt/2019dalam pertimbangannya disebutkan:

Bahwa hanya dengan bukti surat girik yang diterbitkan sebelum Indonesia merdeka yaitu sebelum tahun 1940, fisik tanah tidak pernah dikuasai dalam kurun waktu kurang lebih 70 tahun, tidak dapat dijadikan dasar kepemilikan (yurisprudensi tetap Mahkamah Agung), sebaliknya pihak yang menguasai yaitu Pemerintahan Kabupaten Lombok Timur sekarang Desa sebagai pemilik pecatu yang menguasai kurang lebih selama 70 tahun dan sudah didaftar sebagai aset negara (tanah pecatu) tanggal 10 Januari 1950, berdasarkan hukum pertanahan nasional dinyatakan sebagai pemilik (yurisprudensi tetap Mahkamah Agung);

Pelaksanaan pendaftaran tanah telah diatur secara umum dalam Pasal 19 UUPA No 5 Tahun 1960. Tujuan dan manfaat pendaftaran tanah salah satunya adalah untuk memberikan kepastian hukum dan perlindungan hukum kepada pemegang hak atas tanah suatu bidang dengan diberikannya sertifikat hak atas tanah, sementara. Girik bukanlah surat tanda bukti hak atas tanah, Posisi derajatnya sama dengan Bukti 
Pembayaran Pajak Bumi dan Bangunan. Masyarakat di Indonesia masih mengenal adanya tanah dengan status Girik atau Kekitir atau Petuk diluar sertifikat sebagai bukti sah atas kepemilikan tanah. Menurut Maria S.W. Sumar-djono, dari 55 juta bidang tanah yang ada di Indonesia, baru 30\% yang telah memiliki sertifikat. ${ }^{11}$ Dengan data tersebut menjadi tepat seperti apa yang disimpulkan A.P. Perlindungan ${ }^{12}$, bahwa proses pendaftaran tanah di Indonesia sampai saat ini belum memuaskan, terbukti masih sedikit masyarakat yang melakukan pendaftaran atas tanahnya.

Keberadaan Girik yang digunakan oleh sebagian masyarakat sebagai alat bukti kepemilikan atas tanahnya, sebenarnya hanya merupakan alat bukti pembayaran pajak atas tanah adat atau tanah garapan, atau bukti bahwa atas tanah tersebut telah terdaftar sebagai objek pajak dan dengan demikian harus dibayar pajaknya. Dalam konteks yuridis, status hukum tanah yang hanya menggunakan Girik sebagai bukti kepemilikan atas tanah menjadi tidak kuat karena tidak di akomodasi oleh Undangundang agraria yang berlaku. ${ }^{13}$

Keberadaan Girik yang berkembang di masyarakat yang kemudian dianggap oleh sebagian masyarakat sebagai tanda bukti hak atas tanah kiranya dapat ditelusuri berasal dari pengaruh ketika masih terdapatnya status tanah hak Eropa dan hak Adat sebelum diundangkannya UUPA. ${ }^{14}$

Jenis Pungutan pajak di Indonesia sebagaimana sudah diketahui bahwa sampai pada tahun 1961, di Indonesia dikenal terdapat tiga jenis pungutan pajak yang masingmasing dikenakan sesuai dengan status tanah yang ada, yaitu Verponding Eropa untuk tanah berstatus tanah hak barat, Verponding Indonesia untuk tanah berstatus hak adat yang berada di wilayah Gemeente, dan Landrente atau pajak bumi untuk tanah dengan status hak adat yang berada di luar wilayah Gemeente. Dalam konteks pungutan pajak ini, yang memiliki kewajiban untuk membayar pungutan pajak tersebut adalah hanya pemilik atau pemegang hak atas tanah tersebut. Jadi meskipun yang menguasai tanah meminta untuk dikenakan verponding atau landrente, tetapi kalau tanah yang bersangkutan bukan tanah hak barat atau hak adat, maka tidak akan diberikan. ${ }^{15}$

Girik merupakan bagian dari Tanah adat masa kini yang berlaku sesudah merdeka tahun 1945 sampai sekarang, dengan bukti autentik berupa girik,16 petukpajak dan pipil, ${ }^{17}$ hak agrarische eigendom, ${ }^{18}$ hak atas druwe, ${ }^{19}$ grant sultan ${ }^{20}$ dan hak-hak lainnya

${ }^{11}$ Maria S.W. Sumardjono. Kebijakan Pertanahan antara Regulasi dan Implementasi, Jakarta: Penerbit Buku Kompas, (2001), hlm. 182

12A.P. Parlindungan, Pendaftaran tanah Di Indonesia, Bandung: Mandar Maju, (1990), hlm. 7.

${ }^{13}$ Maria S.W....hlm. 190.

14Boedi Harsono, Hukum Agraria Indonesia,Jakarta: Djambatan, (2008), hlm. 56.

${ }^{15}$ Lihat Urip Santoso, (2005),Hukum Agraria dan Hak-hak Atas Tanah, Jakarta: Prenada

Media

16 Girik adalah tanah milik adat yang dikuasai oleh pribumi yang telah didaftarkan sebelum dansesudah tahun 1945. Lihat Surat Direktur Jenderal Pajak tanggal 27 Maret 1993 No. SE15/PJ.G/1993 tentang keterangan objek pajak

17Petuk pajak yang fungsinya sebagai surat pengenaan dan tanda pembayaran pajak, di kalangan rakyat dianggap dan diperlukan sebagai tanda-tanda bukti pemilikan tanah yang bersangkutan.Lihat B.F. Sihombing, Evolusi Kebijakan Pertanahan dalam Hukum Tanah Indonesia, Jakarta: Gunung Agung, (2004),hlm. 55

${ }^{18}$ Hak agrarische eigendom adalah suatu hak ciptaan pemerintah Belanda yang bertujuan akan memberikan kepada orang-orang Indonesia suatu hak atas tanah yang kuat. 
sesuai dengan daerah berlakunya hukum adat tersebut, serta masih diakui secara internal maupun eksternal. ${ }^{21}$

Secara yuridis formal, Girikbenar-benar diakui sebagai tanda bukti hak atas tanah sebelum UUPA, tetapi setelah berlakunya UUPA girik tidak berlaku lagi. Hal ini juga dipertegas dengan Putusan Mahkamah Agung RI. No. 34/K/Sip/1960, tanggal 19 Februari 1960 yang menyatakan bahwa surat petuk/girik (bukti penerimaan PBB) bukan tanda bukti hak atas tanah. Masih berkembangnya pemahaman bahwa girik merupakan bukti kepemilikan hak atas tanah setelah UUPA, disebabkan adanya anggapan demikian yang masih terus berkembang di kalangan masyarakat, termasuk di kalangan pemerintahan, termasuk di lingkungan peradilan. Dengan dasar bukti tersebut masyarakat sudah merasa aman, karena merasa telah memiliki bukti kepemilikan atas hak tanahnya.

Setelah tahun 1960, Girik atau kikitir tidak mempunyai kekuatan hukum sebagai bukti kepemilikan hak atas tanah, kecuali hanya sebagai alat keterangan objek tanah/bangunan dan sebagai bukti pajak tanah/bangunan. ${ }^{22}$ Menurut AP. Perlindungan ${ }^{23}$ terlalu banyak masalah yang ditimbulkan dari penilaian terhadap tanah adat seperti girik, letter $c$, petuk, grant sultan dan sejenis hak yang berasal dari hakhak adat. Pengadilan direpotkan dengan perkara-perkara tanah yang seharusnya telah dikonversi. Tanah-tanah adat seharusnya sudah dikonversi dan tunduk pada ketentuan UUPA, karena pemerintah tidak mungkin lagi mengeluarkan bukti-bukti hak atas tanah yang tunduk pada sistem hukum yang lama. Sehingga dengan demikian girik, letter $c$, dan tanah-tanah hak adat lainnya tidak dapat lagi dijadikan bukti kepemilikan.

Girik tidak dapat menjadi bukti kepemilikan hak atas tanah. Girik juga tidak kuat dalam melakukan pembuktian dalam kasus sengketa di Pengadilan, kecuali untuk melakukan penggugatan atas bukti lain yang tidak sah, di mana Girik masih harus didampingi oleh penguatan alat bukti lain, seperti surat keterangan Kepala Desa dan atau tentang sejarah kepemilikan tanah tersebut yang benar dan kuat. Girik juga tidak dapat menjadi jaminan untuk memperoleh pinjaman dari lembaga perbankan, berbeda halnya dengan Sertifikat hak atas tanah.

Keberadaan Girik yang justru sering mengundang sengketa dan juga pemahaman yang salah dari masyarakat itulah, maka melalui Surat Edaran Direktur Jenderal Pajak No. SE-15/PJ.6/1993, tanggal 27 Maret 1993, yang kemudian dilakukan penegasan ulang melalui Surat Edaran Direktur Jenderal Pajak No. SE-44/PJ.6/1998, tanggal 11 November 1998, dinyatakan bahwa Girik/Petuk D/Kekitir/Keterangan Objek Pajak (KP PBB. 41) sejak dikeluarkannya surat edaran tersebut dilarang untuk diterbitkan lagi di wilayah Indonesia.

Pembuktian hak lama berdasarkan Pasal 24 dan 25 PP. No. 24 Tahun 1997 tentang Pendaftaran Tanah disebutkan bahwa pembuktian hak lama yang berasal dari

${ }^{19}$ Hak atas druwe adalah hak milik yang dikenal dalam masyarakat Bali. Lihat Soebekti Poesponoto, Asas-asas dan Susunan Hukum Adat,Jakarta: Pradyna Paramita, (1999), hlm. 68.

${ }^{20}$ Grant sultan adalah semacam hak milik adat, diberikan oleh Pemerintah Swapraja,

khusus bagi kawula Swapraja, dan didaftarkan di Kantor Pejabat Swapraja. Lihat Boedi Harsono, Hukum Agraria Indonesia,Jakarta: Djambatan, (2008), hlm. 54.

21Supriadi, Hukum Agraria, Jakarta: Sinar Grafika, (2012), hlm. 14

22Bintatar Sinaga, Keberadaan Girik Sebagai Surat Tanah, Kompas, 24 September 1992

${ }^{23}$ AP. Parlindungan, Konversi Hak-hak atas Tanah Di Indonesia, Kompas, 24 September 
konversi hak lama dibuktikan dengan alat bukti tertulis dan keterangan saksi dan/atau pernyataan pemohon yang kebenarannya dianggap cukup untuk mendaftar oleh Panitia Ajudikasi untuk pendaftaran sistematik atau Kepala Kantor Pertanahan untuk pendaftaran sporadis. Penilaian tersebut didapat atas dasar pengumpulan dan penelitian data yuridis mengenai bidang tanah bersangkutan oleh Panitia Ajudikasi dalam Pendaftaran Tanah secara sistematik atau oleh Kepala Kantor Pertanahan dalam pendaftaran tanah secara sporadik. Atas dasar alat bukti dan berita acara pengesahan, hak atas tanah yang data fisik dan data yuridisnya sudah lengkap dan tidak ada sengketa, dilakukan pembukuan dalam buku tanah dan diterbitkan sertifikat hak atas tanah. Data Yuridis adalah keterangan mengenai status hukum bidang tanah dan satuan rumah susun yang didaftar, pemegang haknya dan hak pihak lain serta bebanbeban lain yang membebaninya (Pasal 1 angka (7) PP No. 24 Tahun 1997. Sedangkan Data Fisik adalah keterangan mengenai letak, batas dan luas bidang tanah dan satuan rumah susun yang didaftar, termasuk keterangan mengenai adanya bangunan atau bagian bangunan di atasnya (Pasal 1 angka (6) PP No. 24 Tahun 1997.

Girik bukan bukti hak atas tanah, tetapi dapat menjadi bukti tertulis untuk melakukan pendaftaran atas tanah yang berasal dari tanah hak adat. Secara langsung atau tidak langsung, sebenarnya pendaftaran tanah dari tanah bekas hak adat berkaitan dengan konversi hak atas tanah tersebut, yang memang sejak keluarnya UUPA, tanah hak adat dan hak Barat harus dikonversi atau disesuaikan atau diubah dari peraturan hukum tanah Indonesia lama menjadi peraturan yang baru.

Putusan Mahkamah Agung RI N0. 287PK/Pdt/2019 dalam pertimbangan majelis hakim menyatakan bahwa:

Bahwa putusan Pengadilan Tinggi yang mengabulkan gugatan Penggugat berdasarkan bukti pembayaran pajak, tidak sejalan dengan yurisprudensi yaitu bukti pembayaran pajak bukan merupakan bukti kepemilikan;

Bahwa dalil Penggugat menyatakan dikuasainya tanah sengketa oleh Tergugat sejak tahun 1950 didasarkan pada hubungan pinjam meminjam tetapi dalil Penggugat itu tidak didukung oleh cukup bukti, dan fakta sebaliknya yang memperkuat posisi Tergugat adalah bahwa Tergugat/Pemohon Peninjauan Kembali telah menguasai tanah sengketa sejak tahun 1950 atas dasar tanah pecatu atau tanah desa;

Dengan demikian pihak manapun yang mengklaim memiliki suatu hak atas tanah harus dapat membuktikan haknya atau membuktikan adanya hubungan hukum kepemilikan antara tanah dengan pihak yang bersangkutan, apabila belum ada sertifikat hak atas tanah, maka girik atau apapun namanya hanya dapat digunakan sebagai bukti permulaan adanya hubungan hukum tersebut yang kemudian diperkuat dengan data fisik yang dapat menjelaskan atau menggambarkan letak, batas, luas bidang dan bukti penguasaan atas tanah secara berturut-turut selama 20 (dua puluh) tahun, apabila tidak ada terdapat data yuridis maupun data fisik atas tanah tersebut.

Surat Giriktanah tidak dapat dijadikan bukti atas kepemilikan hak atas tanah, walaupun Ahli waris Papuq menyatakan bahwa tanah sengketa adalah peninggalan almarhum Papuq Djamilah berdasarkan bukti surat girik. Sebagaimana diketahui dalam kasus tersebut bahwa Kakek moyang Penggugat yaitu almarhum Papuq Djamilah sebelum tahun 1940 tidak pernah menguasai dan sepanjang hidupnya tidak pernah keberatan atas penguasaan tanah oleh pemerintah desa pada saat itu, juga almarhum Among Rawan yang merupakan kakek Penggugat sepanjang hidupnya tidak menguasai tanah objek sengketa dan tidak pernah menyatakan keberatan, 
demikian juga almarhum Awang yang merupakan orangtua dari Penggugat, sepanjang hidupnya tidak menguasai dan tidak pernah keberatan atas tanah objek sengketa sebagai tanah pecatu, selain itu tiga generasi tersebut tidak pernah mengkonversi surat girik tersebut sebagaimana diharuskan oleh peraturan hukum pertanahan, maka Penggugat tidak dapat dinyatakan sebagai pemilik tanah objek sengketa.

Girik adalah surat pajak hasil bumi (verponding), sebelum diberlakukannya UUPA memang merupakan bukti kepemilikan hak atas tanah, tetapi setelah berlakunya UUPA, girik bukan lagi sebagai bukti hak atas tanah, namun hanya berupa surat keterangan objek atas tanah, dengan demikian kedudukan Girik yang dianggap sebagai bukti hak atas tanah tidak dapat disebut sebagai bukti kepemilikan atas tanah, karena tanda bukti kepemilikan tanah yang diakui oleh Peraturan Perundangundangan adalah Sertifikat Hak atas Tanah. ${ }^{24}$

Sertifikat hak atas tanah dihadapkan dengan bukti Girik dalam suatu tuntutan atau gugatan hukum, maka seharusnya bukti girik tanpa didukung dengan bukti lainnya seperti data yuridis dan data fisik dan/atau penguasaan fisik secara terus menerus selama 20 (dua puluh) tahun, tidak dipertimbangkan oleh Majelis Hakim yang memeriksa dan mengadili perkara.

\section{Status Hukum Tanah Pecatu Desa Lenek}

Mahkamah Agung mengabulkan permohonan Peninjauan Kembali dari ParaPemohon melalui Putusan Mahkamah Agung Nomor N0. 287PK/Pdt/2019perihalpermohonan Peninjauan Kembali atas Putusan Mahkamah Agung Nomor 1370 K/Pdt/2016 tanggal 8 November 2016 tentang pengelolaan tanah sengketa oleh Pemerintah Desa Lenek, Kecamatan Aikmel, Kabupaten Lombok Timur. Dalam pertimbangan majelis hakim disebutkan bahwa:

Bahwa almarhum Pauq Djamilah sebagai kakek moyang Penggugat atau ayah dari Kakek Penggugat meninggal dunia tahun 1940, tanah objek sengketa telah dikuasai dan telah dijadikan tanah pecatu, yang setelah Indonesia merdeka tepatnya tanggal 10 Januari 1950 dicatatkan secara resmi sebagai tanah pecatu kemudian menjadi aset di Kabupaten Mataram, tanah itu dikuasai secara terus menerus dan setelah berlaku Undang-Undang Nomor 6 Tahun 2014 tentang Pemerintahan Desa, yang mengatur aset desa harus dipisahkan dengan aset daerah, selanjutnya atas persetujuan DPRD Kabupaten Lombok Timur disusul Surat Keputusan Bupati tanggal 1 Juli 2014 Nomor 188.45/319/PPKA/2014, tanah objek sengketa sebagai aset negara di Kabupaten Lombok Timur (Menteri Keuangan RI) diserahkan kepada Desa sebagai Tanah Pecatu Desa Lenek

Hal tersebut menunjukkan bahwa tanah sengketa tersebut merupakan Tanah Pecatu yang menjadi aset desa Lenek Kecamatan Aikmel, Kabupaten Lombok Timur dan berkekuatan hukum tetap, sebagaimana dalam perimbangan majelis hakim disebutkan bahwa:

Menimbang, bahwa berdasarkan pertimbangan di atas, Mahkamah Agung berpendapat bahwa terdapat cukup alasan untuk mengabulkan permohonan peninjauan kembali dari Para Pemohon Peninjauan Kembali KEPALA DESA LENEK dan kawan-kawan tersebut dan membatalkan

24Boedi Harsono, Hukum Agraria Indonesia,Jakarta: Djambatan, (2008), hlm. 55. 
putusan Mahkamah Agung Nomor 1370 K/Pdt/2016 tanggal 8 November 2016, serta Mahkamah Agung akan mengadili kembali perkara ini dengan amar putusan sebagaimana yang akan disebutkan dibawah ini.

Undang-Undang Pokok Agraria (UUPA) memang tidak dijelaskan secara khusus mengenai tanah pecatu, namun tanah yang serupa dengan tanah pecatu dapat dikatagorikan sebagai hak ulayat karena tanah pecatu masih diatur dengan ketentuan hukum adat setempat, dan melekat hak komunal yang secara umum dalam Pasal 3 Undang-Undang Pokok Agraria menyebutkan

"Pelaksanaan hak ulayat dan hak-hak serupa itu dari masyarakat Hukum Adat, sepanjang menurut kenyataannya masih ada, harus sedemikian rupa sehingga sesuai dengan kepentingan nasional dan Negara, yang berdasarkan atas persatuan bangsa serta tidak boleh bertentangan dengan undang-undang dan peraturan-peraturan yang lebih tinggi."

Tanah pecatu yang dikenal dalam rumpun adat suku sasak di Pulau Lombok dikonsepsikan sebagai tanah yang diberikan kepada pejabat tertentu oleh masyarakat adat untuk menyelenggarakan pemerintahan diwilayahnya berdasarkan prinsip bahwa tanah tersebut diberikan selama yang bersangkutan memangku jabatan. Konsep tanah pecatu mempunyai kesamaan dengan konsep tanah bengkok yang dikenal di Pulau Jawa, yakni Tanah bengkok dapat dianggap suatu pembayaran kepada Kepala Desa oleh persekutuan untuk memelihara keluarganya. ${ }^{25}$ Menilik dari latar historis, tanah pecatu ini dikenal dan dinamakan oleh pemerintah kolonial dengan sebutan "Ambtelijk profitrecht" menurut sejarahnya hal ini lazimnya disebut hak seorang pejabat atas sebidang tanah, Kepala Persekutuan atau Pembesar Desa lain mempunyai hak atas tanah pertanian yang diberikan oleh persekutuan untuk memelihara keluarganya.

Pengaturan tanah pecatu berdasarkan sistem hukum Indonesia diantaranya dalam Undang-undang Nomor 19 tahun 1965, yang dimana setelah berlakunya undang-undang ini maka semua peraturan yang berlaku sebelumnya dinyatakan tidak berlaku lagi. Ketentuan yang mengatur tentang penghasilan pejabat desa terdapat pada pasal 13 ayat (1) Undang-undang Nomor 19 tahun 1965. Pelaksanaan Undangundang Nomor 19 tahun 1965 tidak dapat dilaksanakan sebagaimana mestinya karena terjadi peristiwa pemberontakan, sehingga pemerintah Orde Baru menitik beratkan otonomi seluas-luasnya kepada daerah, Undang-undang Nomor 19 tahun 1965 perlu ditinjau ulang dan untuk mengantisipasi hal tersebut dikeluarkan Instruksi Menteri Dalam Negeri Nomor 29 tahun 1966 tentang penundaan realisasi pembentukan desa praja.

Undang-undang Nomor 5 Tahun 1979 Tentang Pemerintahan Desa kemudian menjadikan tanah pecatu desa dikendalikan penuh oleh Pemerintah Kabupaten. Namun pada tahun 1990 berdasarkan surat perintah Bupati tanah pecatu yang dipegang/dikolola oleh Keliang/Kepala Dusun harus dicabut selanjutnya diperuntukan kepada Kepala desa dan perangkat desa yaitu Sekretaris Desa dan staf desa. Seiring perkembangan maka diterbitkanlah Undang-undang Nomor 22 Tahun 1999 tentang Otonomi Daerah, yang dimana mengenai tanah pecatu masih tetap dikendalikan pemerintah Daerah. Kemudian dikeluarkan Undang-undang Nomor 32

${ }^{25}$ LihatSoerjono Soekanto, Meninjau Hukum Adat Indonesia: Suatu Pengantar Untuk Mempelajari Hukum Adat, Jakarta, Rajawali, (1985), hlm.34. 
tahun 2004 tentang Pemerintahan Daerah. Undang-undang Nomor 32 tahun 2004 mengandung makna dihidupkannya kembali nilai-nilai warisan budaya Indonesia. Dengan berlakunya otonomi daerah berarti penataan kembali pemerintahan desa sesuai dengan kepribadian bangsa Indonesia yang selama ini telah terkubur oleh Undang-undang Nomor 5 tahun 1979. 26

Pengaturan tentang tanah Pecatu dalam hal ini sebagai aset desa selanjutnya dapat dilihat dengan lahirnya Undang-undang Nomor 6 tahun 2014 tentang Desa. Untuk pelaksanaan Undang-undang Nomor 6 tahun 2014 tentang Desa terdapat 2 (dua) Peraturan Pemerintah yaitu Peraturan Pemerintah Nomor 43 Tahun 2014 Tentang Peraturan Pelaksanaan Undang-Undang Nomor 6 Tahun 2014 Tentang Desa, yang telah diubah dengan Peraturan Pemerintah Nomor 47 tahun 2015 tentang Perubahan Atas Peraturan Pemerintah Nomor 43 Tahun 2014 Tentang Peraturan Pelaksanaan Undang-Undang Nomor 6 Tahun 2014 Tentang Desa. Di dalamnya memang tidak secara langsung menyebutkan mengenai tanah pecatu akan tetap mengatakan tanah bengkok atau sejenisnya. Sebelum disahkannya Undang-undang Nomor 6 tahun 2014 tentang Desa. Tanah pecatu ini menjadi hak perangkat desa untuk dikelola sebagai kompensasi gaji mereka, sebagai hak asal usul yang melekat karena jabatannya. Dengan demikian hak pengelolaan tanah pecatu yang diperuntukkan bagi perangkat desa merupakan hak mereka.

Pelaksanaan Undang-undang Nomor 6 tahun 2014 tentang Desa terkait aset desa dalam hal ini tanah pecatu sesuai dengan pertimbangan majelis hakim sebagai berikut:

Bahwa Almarhum Pauq Djamilah sebagai kakek moyang Penggugat atau ayah dari Kakek Penggugat meninggal dunia tahun 1940, tanah objek sengketa telah dikuasai dan telah dijadikan tanah pecatu, yang setelah Indonesia merdeka tepatnya tanggal 10 Januari 1950 dicatatkan secara resmi sebagai tanah pecatu kemudian menjadi aset di Kabupaten Mataram, tanah itu dikuasai secara terus menerus dan setelah berlaku Undang-Undang Nomor 6 Tahun 2014 tentang Pemerintahan Desa, yang mengatur aset desa harus dipisahkan dengan aset daerah, selanjutnya atas persetujuan DPRD Kabupaten Lombok Timur disusul Surat Keputusan Bupati tanggal 1 Juli 2014 Nomor 188.45/319/PPKA/2014, tanah objek sengketa sebagai aset negara di Kabupaten Lombok Timur (Menteri Keuangan RI) diserahkan kepada Desa sebagai Tanah Pecatu Desa Lenek.

Status hukum tanah pecatu selain diatur dalam Undang-Undang Nomor 6 Tahun 2014 tentang Pemerintahan Desa sebagai aset desa, dalam Pasal 18B juga diakui sebagai bagian dari masyarakat hukum adat. Pengakuan dan penghormatan Pasal 18B ayat (2) UUD 1945 tentang kesatuan-kesatuan masyarakat hukum adat serta hak-hak tradisonal nya sepanjang masih hidup dan sesuai dengan perkembangan masyarakat dan prinsip Negara Kesatuan Republik Indonesia, yang diatur dengan UndangUndang. Landasan ini memisahkan antara satuan pemerintahan daerah yang diberi otonomi dengan kesatuan masyarakat hukum. Urusan yang dikelola oleh satuan pemerintahan daerah menunjukkan pemencaran kekuasaan, sementara, sepanjang masih ada, urusan yang dikelola oleh Desa merupakan pengakuan. Tentunya tetap

${ }^{26}$ LihatI Nyoman Sirtha, Aspek Hukum Dalam Konflik Adat Bali, Universitas Udayana Press, Denpasar, (2008), hlm, 11. 
dimungkinkan terdapat tugas pembantuan yang diberikan oleh Kabupaten, Provinsi, maupun Pemerintah Pusat. ${ }^{27}$

Konstitusi pluralis menjadi basis politik pluralism hukum sebagai arahan pengakuan kesatuan masyarakat hukum adat yang memuat prinsip-prinsip:28 (1) pengakuan terhadap kesatuan masyarakat hukum adat, yang meliputi pengakuan sebagai subjek hukum, tata pemerintahan adat, keberlakuan hukum adat dan hak atas benda adat termasuk hak ulayat; (2) pengakuan, penghormatan, perlindungan dan pemenuhan hak-hak kesatuan masyarakat hukum adat sebagai hak asasi manusia, baik hak kolektivitas maupun sebagai hak perorangan warga kesatuan masyarakat hukum adat; (3) responsivitas hukum negara terhadap kemajemukan ada dan nilainilai yang hidup dalam kesatuan masyarakat hukum adat dan (4) partisipasi hukum bagi kesatuan masyarakat hukum adat

Jimmly Asshiddiqie sebagaimana dikutip Marhaendra ${ }^{29}$ telah memposisikan UUD 1945 sebagai konstitusi pluralis dalam arti konstitusi yang mengintegrasikan kemajemukan warga bangsa dalam satu kesatuan system rujukan bernegara berdasarkan Pancasila dan UUD 1945. Istilah "mengintegrasikan" mesti dibaca tidak dalam pengertian meleburkan kemajemukan itu sebagai entitas tunggal, melainkan kemajemukan itu diakomodasikan dalam UUD 1945, dalam pengertian memberikan pengakuan terhadap kemajemukan, dan menghormati dan melindunginya, serta memenuhi hak-hak dari komunitas yang majemuk itu.

Status Tanah Pecatu Desa Lenek pada awalnya memang merupakan bagian dari Tanah adat masa kini yang berlaku sesudah merdeka tahun 1945 sampai sekarang, dengan bukti autentik berupa girik, dan hak-hak lainnya sesuai dengan daerah berlakunya hukum adat tersebut, serta masih diakui secara internal maupun eksternal. ${ }^{30}$ Namun dalam sejarahnya Pihak Pemegang Girik pada saat itu tidak mengkonversikan ${ }^{31}$ kepemilikannya menjadi hak milik pribadi, namun sebaliknya memberikan tanah tersebut untuk dikelola oleh Kepala desa Adat setempat.

Sebagaimana dalam Hak Milik atas tanah ini terjadi karena undang-undanglah yang menciptakannya, sebagaimana yang diatur dalam Pasal I, Pasal II, dan Pasal VII ayat (1) Ketentuan-ketentuan Konversi UUPA. Terjadinya Hak Milik atas tanah ini atas dasar ketentuan konversi (perubahan) menurut UUPA. Sejak berlakunya UUPA pada tanggal 24 September 1960, semua hak atas tanah yang ada harus diubah menjadi salah satu hak atas tanah yang diatur dalam UUPA. ${ }^{32}$

Kemudian karena telah tanah objek sengketa telah dikuasai dan telah dijadikan tanah pecatu, yang setelah Indonesia merdeka tepatnya tanggal 10 Januari 1950

${ }^{27}$ R. Yando Zakaria, Makna Amandemen Pasal 18 UUD 1945 bagi Pengakuan dan Perlindungan Masyarakat Adat di Indonesia, Makalah yang disampaikan pada Konferensi dan Dialog Nasional, (2012).

${ }^{28}$ Lihat Marhaendra Wija Atmaja, "Politik Hukum Adat: Hukum Adat Sebagai Sumber Identitas Tata Hukum Nasional dan Pemaknaan Berideologi Kepastian Hukum," dalam Kertha Patrika, Edisi Khusus, Jurnal Ilmiah Fakultas Hukum Universitas Udayana Denpasar, (2010), hlm. 211.

${ }^{29} \mathrm{Ibid}$

30Supriadi, Hukum Agraria, Jakarta: Sinar Grafika, (2012), hlm. 14

${ }^{31}$ Konversi adalah perubahan hak atas tanah sehubungan dengan berlakunya UUPA. Hak-hak atas tanah yang ada sebelum berlakunya UUPA diubah menjadi hak-hak atas tanah yang ditetapkan dalam UUPA (Pasal 16 UUPA)

${ }^{32}$ Boedi Harsono, Hukum Agraria Indonesia: sejarah pembentukan UUPA, isi dan pelaksanaanya, jakarta: Djambatan, (2005), hlm. 232. 
dicatatkan secara resmi sebagai tanah pecatu kemudian menjadi aset di Kabupaten Mataram, tanah itu dikuasai secara terus menerus. Status tanah tersebut menjadi milik pemerintah Mataram, yakni status kepemilikan tanah dikuasai oleh negara dengan alasan penyerahan sukarela oleh pemiliknya, dimana pemilik membiarkan tanah tersebut dikelola oleh Pemerintah Desa lenek secara terus-menerus. Hal tersebut sesuai dengan hapusnya hak milik karena penyerahan sukarela oleh pemiliknya. Penyerahan dengan sukarela maksudnya bahwa subjek hak melepaskan hak atas tanah yang dimilikinya kepada Negara dengan tanpa adanya ganti kerugian yang diterimanya. Hak atas tanah yang dilepaskan tersebut akan menjadi tanah Negara. ${ }^{33}$

Setelah berlaku Undang-Undang Nomor 6 Tahun 2014 tentang Pemerintahan Desa, yang mengatur aset desa harus dipisahkan dengan aset daerah, selanjutnya atas persetujuan DPRD Kabupaten Lombok Timur disusul Surat Keputusan Bupati tanggal 1 Juli 2014 Nomor 188.45/319/PPKA/2014, tanah objek sengketa sebagai aset negara di Kabupaten Lombok Timur (Menteri Keuangan RI) diserahkan kepada Desa sebagai Tanah Pecatu Desa Lenek.

Pengalihan status tanah pecatu dari aset Pemerintah mataram menjadi aset Desa Lenek berdasarkan Surat Keputusan Bupati tanggal 1 Juli 2014 Nomor 188.45/319/PPKA/2014, tanah objek sengketa sebagai aset negara di Kabupaten Lombok Timur (Menteri Keuangan RI) diserahkan kepada Desa sebagai Tanah Pecatu Desa Lenek merupakan hal yang sudah sesuai dengan Undang-Undang Nomor 6 tahun 2014 tentang Desa, diantaranya dalam pasal 76 yang menyebutkan;

Ayat (1) Aset Desa dapat berupa tanah kas Desa, tanah ulayat, pasar Desa, pasar hewan, tambatan perahu, bangunan Desa, pelelangan ikan, pelelangan hasil pertanian, hutan milik Desa, mata air milik Desa, pemandian umum, dan aset lainnya milik Desa."

Ayat (3) Kekayaan milik Pemerintah dan Pemerintah Daerah berskala lokal Desa yang ada di Desa dapat dihibahkan kepemilikannya kepada Desa."

Ayat (5) Kekayaan milik Desa yang telah diambil alih oleh Pemerintah Daerah Kabupaten/Kota dikembalikan kepada Desa, kecuali yang sudah digunakan untuk fasilitas umum.

Selain itu pengalihan status tanah tersebut merupakan bentuk hak milik atas tanah yang terjadi karena penetapan pemerintah yang sudah ditetapkan oleh UndangUndang Pokok Agraria, dimana diberikan kepada instansi yang berwenang dengan cara dan syarat-syarat yang ditetapkan dan tanah yang diberikan semula berstatus tanah negara. ${ }^{34}$ Adapun tanah yang termasuk dalam cakupan penguasaan negara adalah seluruh tanah yang berada di wilayah Indonesia, kecuali tanah yang sudah di haki. ${ }^{35}$

Berdasarkan uraian diatas, maka dapat disimpulkan bahwa status Tanah Pecatu Desa Lenek dikatagorikan sebagai bagian dari hak ulayat dengan alasan tanah pecatu masih diatur dengan ketentuan hukum adat setempat dan melekat hak komunal, hal ini sebagai Domain Privat Desa Lenek dan bukan Domain Publik dibawah Pemerintahan Kabupaten/Kota. Sementara Kedudukan Hukum Tanah Pecatu Desa

${ }^{33}$ Ibid, hlm. 343.

34 Eddy Ruchiyat, Politik Pertanahan Nasional Sampai Orde Reformasi, Bandung: P.T. Alumni, (2006), hlm. 49

35Urip Santoso, Hukum Agraria Kajian Komprehensif, Jakarta: Kencana Prenada Media, (2012), hlm. 22 
Lenek berkekuatan hukum tetap berdasarkan Putusan Mahkamah Agung RI N0. 287PK/Pdt/2019 yang mengabulkan permohonan para pemohon peninjauan kembali dan dalam hal ini menunjukkan bahwa tanah yang disengketakan dan di klaim oleh ahli waris Papuq Djamilah tidak sah karena hanya berdasarkan bukti Girik, dan sebaliknya menguatkan Pemerintah Desa Lenek (Para pemohon PK) bahwa tanah tersebut merupakan Tanah Pecatu Desa lenek dengan bukti persetujuan DPRD Kabupaten Lombok Timur disusul Surat Keputusan Bupati tanggal 1 Juli 2014 Nomor 188.45/319/PPKA/2014, tanah objek sengketa sebagai aset negara di Kabupaten Lombok Timur (Menteri Keuangan RI) diserahkan kepada Desa sebagai Tanah Pecatu Desa Lenek.

\section{Kesimpulan}

Status Tanah Pecatu Desa Lenek dikategorikan sebagai domain privat yaitu bagian dari hak ulayat dengan alasan tanah pecatu masih diatur dengan ketentuan hukum adat setempat dan melekat hak komunal, Tanah pecatu sebagai Domain Privat Desa Lenek dan bukan Domain Publik dibawah Pemerintahan Kabupaten/Kota. Sementara Kedudukan Hukum Tanah Pecatu Desa Lenek berkekuatan hukum tetap berdasarkan Putusan Mahkamah Agung RI N0. 287PK/Pdt/2019 yang mengabulkan permohonan peninjauan kembali para pemohon dan dalam hal ini menunjukkan bahwa tanah yang disengketakan dan di klaim oleh ahli waris Papuq Djamilah tidak sah karena hanya berdasarkan bukti Girik, yang mana bukti girik tanah merupakan bagian dari bukti objek pajak dan bukan sebagai bukti kepemilikan tanah. Sebaliknya Pemerintah Desa Lenek (Para pemohon PK) menunjukkan bahwa tanah tersebut merupakan Tanah Pecatu Desa lenek berdasarkan bukti bahwa tanah objek sengketa telah dikuasai dan telah dijadikan tanah pecatu, yang setelah Indonesia merdeka tepatnya tanggal 10 Januari 1950 dicatatkan secara resmi sebagai tanah pecatu kemudian menjadi aset di Kabupaten Mataram, tanah tersebut dikuasai secara terus menerus dan setelah berlaku Undang-Undang Nomor 6 Tahun 2014 tentang Pemerintahan Desa, yang mengatur aset desa harus dipisahkan dengan aset daerah, selanjutnya atas persetujuan DPRD Kabupaten Lombok Timur disusul Surat Keputusan Bupati tanggal 1 Juli 2014 Nomor 188.45/319/PPKA/2014, tanah objek sengketa sebagai aset negara di Kabupaten Lombok Timur (Menteri Keuangan RI) diserahkan kepada Desa sebagai Tanah Pecatu Desa Lenek.

\section{Daftar Pustaka \\ Buku}

A.P. Parlindungan. Pendaftaran tanah Di Indonesia. Bandung: Mandar Maju, 1990.

B.F. Sihombing.. Evolusi Kebijakan Pertanahan dalam Hukum Tanah Indonesia, Jakarta: Gunung Agung, 2004.

Boedi Harsono. Hukum Agraria Indonesia: Sejarah Pembentukan UUPA, Isi dan Pelaksanaanya. Jakarta: Djambatan, 2005.

Boedi Harsono. Hukum Agraria Indonesia. Jakarta: Djambatan, 2008.

Eddy Ruchiyat. Politik Pertanahan Nasional Sampai Orde Reformasi. Bandung: P.T. Alumni, 2006.

Herlambang P Wiratraman. Laporan Akhir Tim Pengkajian Konstitusi Tentang Perlindungan Hukum Terhadap Masyarakat Hukum Adat, Jakarta: BPHN Kemenkumham RI, 2014. 
I Nyoman Sirtha. Aspek Hukum Dalam Konflik Adat Bali. Denpasar: Universitas Udayana Press, 2008.

J.J. Brugink. Rechtsreflecties, Alih bahasa Arif Sidartha, Bandung: Citra Aditya Bakti, 1995.

Jhonny Ibrahim. Teori dan Metode Penemuan Hukum Normatif. Malang: Banyumedia, 2005.

Maria S.W. Sumardjono. Kebijakan Pertanahan antara Regulasi dan Implementasi, Jakarta: Penerbit Buku Kompas, 2001.

Mukti Fajar ND. Dualisme Penelitian Hukum Normatif dan Empiris. Yogyakarta: Pustaka Pelajar, 2010.

Peter Mahmud Marzuki. Penelitian Hukum. Jakarta: Prenada Media, 2008.

R. Yando Zakaria. Makna Amandemen Pasal 18 UUD 1945 bagi Pengakuan dan Perlindungan Masyarakat Adat di Indonesia, Makalahdalam Konferensi dan Dialog Nasional, 2012.

Rikardo Simarmata. Pengakuan Hukum terhadap Masyarakat Adat Indonesia. Jakarta: UNDP, 2006.

Soebekti Poesponoto. Asas-asas dan Susunan Hukum Adat. Jakarta: Pradyna Paramita, 1999.

Soerjono Soekanto. Pengantar Penelitian Hukum. Jakarta: Universitas Indonesia Press, 1983.

SoerjonoSoekanto. Meninjau Hukum Adat Indonesia: Suatu Pengantar Untuk Mempelajari Hukum Adat. Jakarta: Rajawali, 1985.

Supriadi, Hukum Agraria. Jakarta: Sinar Grafika, 2012.

Urip Santoso. Hukum Agraria dan Hak-hak Atas Tanah, Jakarta: Kencana Prenada Media, 2005.

Urip Santoso. 2012. Hukum Agraria Kajian Komprehensif, Jakarta: Kencana Prenada Media.

\section{Jurnal}

Husni, Anang. "Hak Atas Tanah Pecatu Desa Berdasarkan Prinsip Menguasai oleh Negara." Jurnal IUS 1 (2013). 311-339.

Marhaendra Wija Atmaja. 2010. "Politik Hukum Adat: Hukum Adat Sebagai Sumber Identitas Tata Hukum Nasional dan Pemaknaan Berideologi Kepastian Hukum," dalam Kertha Patrika, Edisi Khusus, Jurnal Ilmiah Fakultas Hukum Universitas Udayana Denpasar, (2010).

\section{Lainnya}

AP. Parlindungan. "Konversi Hak-hak atas Tanah Di Indonesia".Kompas, 24 September 1999

Bintatar Sinaga. "Keberadaan Girik Sebagai Surat Tanah", Kompas, 24 September 1992

Surat Direktur Jenderal Pajak tanggal 27 Maret 1993 No. SE15/PJ.G/1993 tentang keterangan Objek Pajak 